\title{
Effect of dramatic alteration of landscape structure on the Orthoptera assemblages of Transcarpathian lowland meadows (West Ukraine)
}

\author{
Sz. Szanyi ${ }^{1}$ (1) $\cdot$ L. Potish ${ }^{2} \cdot$ I. A. Rácz ${ }^{3} \cdot$ Z. Varga ${ }^{3} \cdot$ A. Nagy ${ }^{1}$ (1)
}

Received: 6 February 2020 / Accepted: 28 July 2021 / Published online: 14 August 2021

(c) The Author(s) 2021

\begin{abstract}
Traditional and extensively used agricultural lands maintain and protect high levels of biological diversity. This diversity is in decline due to land use intensification and abandonment. Natural and semi-natural grasslands of the Carpathian lowlands have become endangered over the 19th century. However, some remains of former wetlands have survived land use change in the Bereg Region (North-eastern Hungary and Eastern Ukraine). We surveyed Orthopterans as sensitive indicators of habitat structure and microclimate in grasslands. We identified three different Orthoptera assemblages and their character species. Although rare and especially valuable species were not found in the studied sites, the species rich remains of wetlands still protected relics of former wildlife of wetlands. Understanding the quantitative character of the assemblages, ratios of life forms and particularly co-occurrences of their character species (Chorthippus dorsatus, Leptophyes albovittata, Tettigonia viridissima and Ruspolia nitidula) and use of Grasshopper Conservation Indexes (GCI) can help to identify remaining good quality patches with highest conservation value and monitoring.

Implications for insect conservation The focused management of these habitats with reconsideration of the traditional water management can be effective practice for wetland management and Orthoptera conservation.
\end{abstract}

Keywords Habitat associations · Abandonment $\cdot$ Character species $\cdot$ Landscape structure $\cdot$ Land use $\cdot$ Biodiversity loss

\section{Introduction}

Extensively and traditionally used European agricultural lands once maintained and protected significant biological diversity (Dover et al. 2010; Habel et al. 2013; Feurdean et al. 2018) due to intermediate disturbance of natural habitats (Wilson 1994; Townsend et al. 1997). This diversity has impoverished and become potentially endangered throughout Europe due to the intensification of land use, the

A. Nagy

nagyanti@agr.unideb.hu

1 Faculty of Agricultural and Food Sciences and Environmental Management, Institute of Plant Protection, University of Debrecen, P.O.B. 400, Debrecen, H-4002, Hungary

2 Department of Forestry, Faculty of Geography, Uzhhorod National University, Universytetska st., 14, Uzhgorod 88000, Ukraine

3 Department of Evolutionary Zoology, Faculty of Science and Technology, University of Debrecen, Egyetem tér 1, Debrecen H-4032, Hungary abandonment of traditional management practices (Cremene et al. 2005; Schmitt and Rákosy 2007; Van Zanten et al. 2014), and as a consequence of extreme change to landscape structures (Meeus et al. 1990; Klijn 2004; Poschlod et al. 2005, 2009).

One of the remaining pockets of this past diversity is the Bereg Plain. The Bereg Plain is located in the north-eastern part of the Pannonian Lowland and is a unique biogeographical region in eastern Central Europe, located on the two sides of the Hungarian-Ukrainian border. This is the coldest part of the Hungarian Great Plain with regular climate extremes due to strong continental climatic influence (Simon 1953). Its special mosaic landscape structure is a result of its transitional geographical situation, edaphic factors, and varied types of land uses. The region is characterized by a mosaic of gallery forests, a variety of semi-natural or disturbed grasslands, and arable lands, which support high insect diversity (Szanyi et al. 2015b). Thanks to remaining undisturbed natural and semi-natural habitats, the region is home to numerous species that are protected by Hungarian and EU legislation (Varga 1992; Evans 2006; Habitats Scientific Committee 2013; Nagy and Rácz 2014; Szanyi et al. 
2015a, 2018; Szanyi and Varga 2015; Nagy et al. 2015). Forests are mostly soft- and hardwood gallery forests. Hardwood gallery forests often associated with hornbeam oakwoods and forming mosaics with different kinds of humid and mesic grasslands (Fekete and Varga 2006).

Considerable parts of the Bereg Plain region formerly belonged to extended wetlands of the Szernye Marsh. The once boggy-marshy habitats have been converted to seminatural humid, mesic and even xeric grasslands and arable lands as a result of river control and the drainage of large marshy areas since the nineteenth century (Szernye- and Ecsedi Marsh, Lovassy 1931). Grasslands have been used as hayfields and pastures during the 2000's (Botlik 2008), but their area has been permanently decreased and fragmented. The remains of humid natural and semi-natural grasslands and their wildlife became endangered by the abandonment and further intensification of land use over the past few years. During the change of the regional climate in the last two decades the region became more and more arid, causing further danger. Although the remains of the gallery forest are partly protected in the Velyka Dobron Wildlife Reserve, but grasslands are out of this legislative protection and suffer also from the lack of conservation activities.

Despite of the eventful history in the region, the biological and landscape diversity of the area is still relatively high, because the natural and semi-natural habitats, traditionally cultivated and intensively used agricultural lands make a colourful mosaic. More than half of the area are under agricultural use. The grasslands used to be managed regularly (e.g. grazing, reaping, burning, etc.), but most of these patches have been abandoned by now. The abandonment led to secondary succession gaining over the area and has led to decreasing species richness (Warren 1997; Baur et al. 2006; Wenzel et al. 2006; Schmitt and Rákosy 2007; Csergő et al. 2013).

Making recommendations for conservation activities and management of these habitats requires an inventory to establish the conservation value and status of the different habitat types. Setting priorities for further conservation strategies also require that we identify the main factors effecting species composition and diversity. In case of grasslands, one of the most suitable indicators are the Orthopterans (Báldi and Kisbenedek 1997; Andersen et al. 2001) because these insects are especially sensitive to changes of habitat structure caused by either anthropogenic or natural processes.

Here we evaluate the effects of land use, land use intensity, and disturbances on the Orthoptera assemblages. We identify character species to be used in habitat characterisation, evaluation of natural value, and monitoring of grasslands. Conservation value of habitat types was also characterised by a modified grasshopper conservation index (GCI) followed Matenaar et al. (2015). Based on these results we provide data for establishment of the legislative protection of characteristic grasslands and Orthoptera species and serve a basis to prioritisation for conservation and management. The first records of the Orthoptera fauna of Transcarpathia were published by Pungur (1899) and Obenberger (1926), and the fauna of the Bereg Plain was firstly studied in the 1950's (Likovitch 1957, 1959). Research has intensified over the past decade and the most recent checklist of the Orthoptera fauna contains 52 species (24 Ensifera, 28 Caelifera; Szanyi et al. 2015a). For lack of historical data long-term history of the Orthoptera fauna and assemblages cannot be evaluated, thus we followed the principles of space-for-time substitution (see e.g. Blois et al. 2013) as is common in similar situations and provide a comparative analysis of Orthoptera assemblages from a series of grasslands sampled in 2013 and characterise these assemblages based on their composition.

\section{Material and methods}

The main part of our study area was located on the Transcarpathian side of the historical Bereg County. Orthoptera assemblages of 20 grasslands representing different habitats and land use types were studied in 2013 (Table 1, Fig. 1). Samplings were conducted twice during the vegetation period, using a combination of sweep netting and direct search. This combined method is known to provide the most complete species overview, it causes little disturbance at the sites and is also a cost-effective method for sampling Orthopteras (Nagy et al. 2007). First sampling was carried out between 15-18th June, and the second was made between 18-21st August. In the mowed sites first sampling was made before and second was made after mowing. Grazed sites were grazed during the whole vegetation period.

Sweep net samples were taken by 200 sweeps with a net of $50 \mathrm{~cm}$ in diameter. The net was emptied after every 50 sweeps to protect sampled individuals, especially the rare and legally protected ones. Sampling was done in calm and sunny weather between 9-12 am and 2-5 pm when the sampled species were equally active. The direct search was made by walking along parallel transects for 15-20 min at each sampling site and we recorded specimens based on both visual and acoustic detections along $2 \mathrm{~m}$ wide transects. Song stemming from outside the transects were ignored. The transects represented all the habitat patches present at the sampling sites and covered about $2500 \mathrm{~m}^{2}(50 \times 50 \mathrm{~m})$ in each site. The collected material was identified at species level according to Harz $(1957,1960,1975)$. We followed the Orthoptera species file data base (Cigliano et al. 2020) for nomenclature. Data of two samplings were summarized by sites.

We used Principal Coordinate (PCoA) and cluster analysis with Bray-Curtis distance to compare the sites based on 
Table 1 List of the Orthoptera sampling sites of the Ukrainian part of the Bereg Plain (West Ukraine) studied in 2013 with their GPS coordinates, a priori categories of habitat types (type: xer-xeric, mes- mesic, hum-humid), land use (use: graz-grazed, mow-mowed, abanabandoned) and intensity of disturbance (dist.: low, med-medium, high)

\begin{tabular}{|c|c|c|c|c|c|c|}
\hline Code & Habitat & Type & Use & Dist. & GPS: N & GPS: E \\
\hline Hum1 & Semi-natural meadow, remain of the Szernye Marsh, partly mowed & Hum & Mow & Med & $48^{\circ} 20^{\prime} 54^{\prime \prime}$ & $22^{\circ} 23^{\prime} 47^{\prime \prime}$ \\
\hline Hum2 & Meadow partly and occasionally grazed by cows & Hum & Aban & Low & $48^{\circ} 18^{\prime} 19^{\prime \prime}$ & $22^{\circ} 21^{\prime} 03^{\prime \prime}$ \\
\hline Hum3 & Wet grassland and shrubs formed in the place of small old forest clearing & Hum & Aban & Low & $48^{\circ} 18^{\prime} 10^{\prime \prime}$ & $22^{\circ} 23^{\prime} 44^{\prime \prime}$ \\
\hline Hum4 & Meadow on hillfoot of the Beregovo Hill, occasionally grazed by cows and goats & Hum & Aban & Low & $48^{\circ} 12^{\prime} 45^{\prime \prime}$ & $22^{\circ} 41^{\prime} 47^{\prime \prime}$ \\
\hline Mes1 & Drained meadow with remains of former wet grassland, grazed by cows & Mes & Graz & Med & $48^{\circ} 26^{\prime} 41^{\prime \prime}$ & $22^{\circ} 16^{\prime} 30^{\prime \prime}$ \\
\hline Mes2 & Grassland mowed twice a year by rotary grass cutter & Mes & Mow & High & $48^{\circ} 27^{\prime} 48^{\prime \prime}$ & $22^{\circ} 18^{\prime} 35^{\prime \prime}$ \\
\hline Mes3 & Drained meadow surrounded by mixed gallery forests, partly mowed & Mes & Mow & Med & $48^{\circ} 27^{\prime} 47^{\prime \prime}$ & $22^{\circ} 20^{\prime} 54^{\prime \prime}$ \\
\hline Mes4 & Drained meadow surrounded by mixed hardwood forests, partly mowed by hand & Mes & Mow & Low & $48^{\circ} 20^{\prime} 41^{\prime \prime}$ & $22^{\circ} 32^{\prime} 12^{\prime \prime}$ \\
\hline Xer1 & Abandoned arable land covered by weeds & Xer & Aban & Low & $48^{\circ} 22^{\prime} 17^{\prime \prime}$ & $22^{\circ} 19^{\prime} 18^{\prime \prime}$ \\
\hline Xer2 & Disturbed grassland grazed by cows & Xer & Graz & High & $48^{\circ} 24^{\prime} 05^{\prime \prime}$ & $22^{\circ} 26^{\prime} 27^{\prime \prime}$ \\
\hline Xer3 & Pasture with high cover of tallgrass trodden by cars and humans & Xer & Aban & Med & $48^{\circ} 22^{\prime} 06^{\prime \prime}$ & $22^{\circ} 24^{\prime} 39^{\prime \prime}$ \\
\hline Xer4 & Large grassland surrounded by arable lands, mowed by rotary grass cutter & Xer & Mow & Med & $48^{\circ} 20^{\prime} 36^{\prime \prime}$ & $22^{\circ} 24^{\prime} 23^{\prime \prime}$ \\
\hline Xer5 & Drained pasture, partly mowed by hand & Xer & Mow & Low & $48^{\circ} 22^{\prime} 15^{\prime \prime}$ & $22^{\circ} 32^{\prime} 24^{\prime \prime}$ \\
\hline Xer6 & Grassland with small mesic patches, partly mowed by rotary grass cutter & Xer & Mow & Med & $48^{\circ} 21^{\prime} 40^{\prime \prime}$ & $22^{\circ} 31^{\prime} 16^{\prime \prime}$ \\
\hline Xer7 & Pasture with low and sparse vegetation, grazed by sheep & Xer & Graz & High & $48^{\circ} 18^{\prime} 54^{\prime \prime}$ & $22^{\circ} 23^{\prime} 19^{\prime \prime}$ \\
\hline Xer8 & Drained meadow, former arable land, grazed by goats & Xer & Graz & High & $48^{\circ} 19^{\prime} 28^{\prime \prime}$ & $22^{\circ} 25^{\prime} 37^{\prime \prime}$ \\
\hline Xer9 & Grassland on hillfoot of the Shom Hill, partly and occasionally grazed by goats and cows & Xer & Graz & High & $48^{\circ} 16^{\prime} 54^{\prime \prime}$ & $22^{\circ} 26^{\prime} 52^{\prime \prime}$ \\
\hline Xer10 & Pasture on a roadside intensively grazed by cows & Xer & Graz & High & $48^{\circ} 14^{\prime} 42^{\prime \prime}$ & $22^{\circ} 33^{\prime} 18^{\prime \prime}$ \\
\hline Xer11 & Large grassland intensively grazed by cows & Xer & Graz & High & $48^{\circ} 15^{\prime} 16^{\prime \prime}$ & $22^{\circ} 36^{\prime} 40^{\prime \prime}$ \\
\hline Xer12 & Grassland intensively grazed by cows & Xer & Graz & High & $48^{\circ} 12^{\prime} 51^{\prime \prime}$ & $22^{\circ} 33^{\prime} 28^{\prime \prime}$ \\
\hline
\end{tabular}

Fig. 1 Location of the Orthoptera sampling sites of the Ukrainian part of the Bereg Plain (West Ukraine) studied in 2013. For detailed information of sites see Table 1. ( $h$ hum, $m$ mes, $x$ xer)

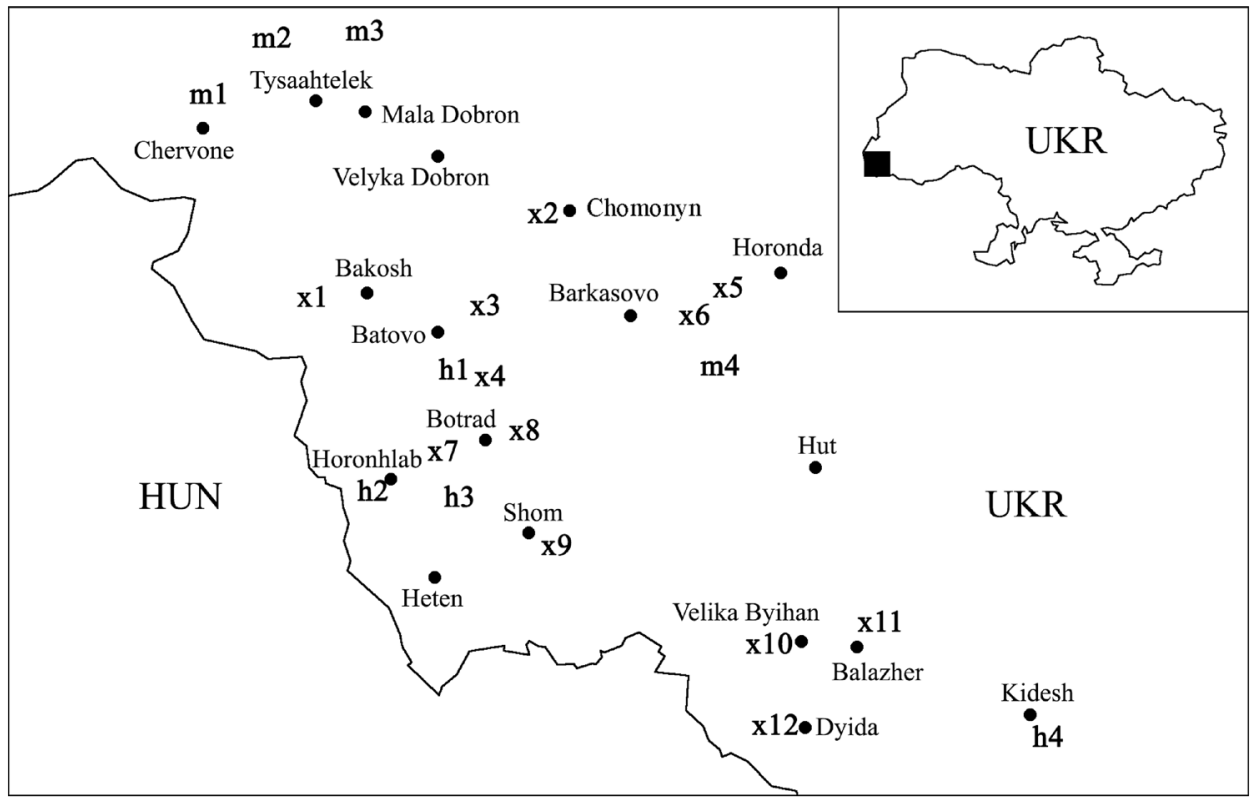

the composition of Orthoptera assemblages. We used the Ward- Orlóci agglomeration method for clustering (Podani 1997a). We used the relative frequency of species by sites for multivariate analyses in the SynTax 2000 software (Podani 1997b).
We categorized sampling sites based on wetness (xeric, mesic, humid habitat types) that also means vegetation structure categories from dense and tall (humid) to sparse and medium sized (xeric) grasslands. All the four humid sites have been covered by grasslands since the 18 th century 
based on the military maps (https://mapire.eu/hu/), but their habitat structure can not be seen original because of the radical changes of the whole landscape. Only the "hum3" site was forested in a relatively short period in the first half of the 20th century. The mesic and xeric sites were mainly forested in the 18th century and after that they were altered to meadows and arable lands with temporary alternate land use.

Besides we used ternary categories for disturbance or land use intensity: low disturbance: no land use (abandoned sites) or low intensity land use with occasional grazing (livestock density <2.0 livestock unite (LSU)/ha (Eurostat 2020), or partly mowed by hand; medium disturbance: mowed by rotary grass cutter, or other medium disturbances (e.g. trodden by cars and humans); high disturbance: intensive grazing ( $\geq 2 \mathrm{LSU} / \mathrm{ha}$ ) and/or mowed by rotary grass cutter (Table 1 ). We identified the type of land use (mowed, grazed, abandoned) and compared the correspondence between these a priori categories and groups formed based on the multivariate analyses.

Assemblage types established by the multivariate analyses were characterised and compared based on their total species richness, mean number of species, mean number of individuals, and mean relative frequencies of faunal groups and life forms. To characterise and compare assemblages Whittaker's index ( $\mathrm{S} / \alpha ; \mathrm{S}=$ number of species, $\alpha=$ mean number of species) was also calculated for both assemblage types and the whole sample (Whittaker 1960). Species were grouped into life forms and faunal elements according to Rácz (1998). We used only four primary life form types because of the relatively low number of species.

To evaluate the conservation value of the habitat types a modified grasshopper conservation index (GCI') was used based on Matenaar et al. (2015). They used three parameters: endemism, dispersal capacity and rarity and each of them was grouped in three classes. The parameters were summed for each species and divided by nine (the maximum value) to obtain a GCI value between zero and one. Considering the distribution of the species live in the studied assemblages (there were no endemic species in the studied sites), instead of endemism the rarity of the species in Hungary, that cover about the $90 \%$ of the Pannonian Biogeographical Region, were used based on categories of Rácz (1998) and Nagy and Rácz (2007): common (=1), frequent (=2), low frequent $(=3)$, scattered $(=4)$ and rare $(=5)$. In case of dispersal capacity and rarity the original method was followed but the parameters were grouped in five categories following the categorization of Nagy and Rácz (2007). For dispersal capacity the groups of migrant $(=1)$, well flying $(=2)$, poorly flying $(=3)$, wing-dimorphic $(=4)$ (contains also mesopterous mainly flightless species) and flightless $(=5)$ (contains wingless, macropterous and mesopterous flightless species) species were used. The local rarity was measured upon the occurrence of a species in the studied sites. A species was considered as common $(=1)$ when it occurred at $\geq 11$ sites, frequent $(=2)$ at $\geq 9$ sites, low frequent $(=3)$ at $\geq 6$ sites, scattered $(=4)$ at $\geq 3$ and rare $(=5)$ at one or two sites. The two parameters were summed and divided by 15 (the maximum value) to obtain a GCI' value between zero and one. The GCI value of the study sites were determined as a sum of the values of the species of the given site. Habitat types was characterised by the mean number of the GCI values of sites. The modified standardized grasshopper conservation index (GCIn') was also calculated for sites by dividing GCI' by the number of species on the given site. While the value of GCI belongs to both species number and value of the species, the GCIn' is not influenced by the species richness Matenaar et al. (2015).

Character species ("indicator" species) of the assemblages were identified using the IndVal method with the program IndVal (Dufrêne and Legendre 1997). We hierarchically classified the species according to their fidelity within groups of sites. The IndVal (IV) value of the species is highest (100) when the given species is present in all samples of the given group and is also exclusive for this group of samples. The program calculates the IV values of each species at each hierarchy level of the clustering. The indicator value is given by the maximum value. The significance of IV values was determined by randomisation (1000 iterations).

\section{Results}

We found 28 Orthoptera species (10 Ensifera: 9 Tettigonioidea and 1 Grylloidea; 18 Caelifera) occurring at the 20 sampling sites involved in this study (Table 2). The most common and abundant species of the region are also common in the study area. Besides these common species, we also found regionally less common species, such as Conocephalus dorsalis, Bicolorana bicolor, Pholidoptera fallax, Aiolopus thallasinus, Stethophyma grossum, Euthystira brachyptera, Stenobothrus crassipes, S. lineatus, Omocestus haemorrhoidalis, Euchorthippus declivus, and three Tetrix species (T. bipunctata, T. subulata and T. tenuicornis). Endangered and rare species of the Bereg region (e.g. Isophya stysi (Cejchan, 1957), Poecilimon schmidtii (Fieber, 1853) and Odontopodisma rubripes (Ramme, 1931)) were absent in the samples. Additionally, Mantis religiosa, the only mantid species of the region, was found at 8 sampling sites.

The total number of sampled individuals was 988 . In the whole sample, Pseudochorthippus and Chorthippus species reached the highest relative frequencies (RF: P. parallelus $36.3 \%$, C. oschei $15.9 \%$ and C. dorsatus $9.2 \%$ ) while the relative frequency of Roeseliana roeselii (6.7\%) and Conocephalus fuscus (5.9\%) also exceeded 5\%. 
Table 2 Orthoptera species occur in the 20 sampling sites of the Ukrainian part of the Bereg Plain with their geographical range, faunal type and life forms (Rácz 1998)

\begin{tabular}{|c|c|c|c|}
\hline Species & Geographical range & Faunal type & Life form \\
\hline Phaneroptera falcata (Poda, 1761) & Eu-Si & $\mathrm{Si}-\mathrm{Pc}$ & Th \\
\hline Leptophyes albovittata (Kollar, 1833) & $\mathrm{Eu}$ & Po-Med & $\mathrm{Th}$ \\
\hline Conocephalus fuscus (Fabricius, 1793) & $\mathrm{Eu}-\mathrm{Si}$ & $\mathrm{Si}-\mathrm{Pc}$ & Th \\
\hline Conocephalus dorsalis (Latreille, 1804) & $\mathrm{Eu}-\mathrm{W}-\mathrm{As}$ & Po-Ca & Th \\
\hline Ruspolia nitidula (Scopoli, 1786) & Af-Eu-Si & Af & Th \\
\hline Tettigonia viridissima Linnaeus, 1758 & $\mathrm{Eu}-\mathrm{Si}$ & $\mathrm{Si}-\mathrm{Pc}$ & $\mathrm{Th}$ \\
\hline Bicolorana bicolor (Philippi, 1830) & $\mathrm{Eu}-\mathrm{Si}$ & An & $\mathrm{Ch}$ \\
\hline Roeseliana roeselii (Hagenbach, 1822) & $\mathrm{Eu}$ & Po-Ca & $\mathrm{Ch}$ \\
\hline Pholidoptera fallax (Fischer, 1853) & S-Eu & Po-Med & $\mathrm{Ch}$ \\
\hline Oecanthus pellucens (Scopoli, 1763) & S-Eu & Po-Med & $\mathrm{Ch}$ \\
\hline Aiolopus thalassinus (Fabricius, 1781) & $\operatorname{Cos}$ & Af & $\mathrm{G}-\mathrm{Ch}$ \\
\hline Stethophyma grossum (Linnaeus, 1758) & $\mathrm{Eu}-\mathrm{Si}$ & Ma & $\mathrm{Ch}$ \\
\hline Mecostethus parapleurus (Hagenbach, 1822) & $\mathrm{Eu}-\mathrm{Si}$ & Ma & $\mathrm{Ch}$ \\
\hline Chrysochraon dispar (Germar, 1834) & $\mathrm{Eu}-\mathrm{Si}$ & An & $\mathrm{Ch}$ \\
\hline Euthistyra brachyptera (Ocskay, 1826)* & Eu-Si & An & $\mathrm{Ch}$ \\
\hline Stenobothrus crassipes (Charpentier, 1825) & $\mathrm{Eu}-\mathrm{Si}$ & Po-Med & $\mathrm{Ch}$ \\
\hline Stenobothrus lineatus (Panzer, 1796) & $\mathrm{Eu}-\mathrm{Si}$ & An & $\mathrm{Ch}$ \\
\hline Omocestus haemorrhoidalis (Charpentier, 1825) & Eu-Si & An & $\mathrm{Ch}$ \\
\hline Omocestus rufipes (Zetterstedt, 1821) & Eu-Si & An & $\mathrm{Ch}$ \\
\hline Chorthippus biguttulus (Linnaeus, 1758) & $\mathrm{Eu}$ & Po-Ca & $\mathrm{Ch}$ \\
\hline Chorthippus brunneus (Thunberg, 1815) & $\mathrm{Eu}-\mathrm{Si}$ & An & $\mathrm{Ch}$ \\
\hline Chorthippus dorsatus (Zetterstedt, 1821) & $\mathrm{Eu}-\mathrm{Si}$ & $\mathrm{Si}-\mathrm{Pc}$ & $\mathrm{Ch}$ \\
\hline Chorthippus oschei Helversen, 1986 & $\mathrm{Eu}-\mathrm{Si}$ & $\mathrm{Si}-\mathrm{Pc}$ & $\mathrm{Ch}$ \\
\hline Pseudochorthippus parallelus (Zetterstedt, 1821) & $\mathrm{Eu}-\mathrm{Si}$ & An & $\mathrm{Ch}$ \\
\hline Euchorthippus declivus (Brisout de Barneville, 1848) & $\mathrm{Se}-\mathrm{Eu}$ & N-Med-Pc & $\mathrm{G}-\mathrm{Ch}$ \\
\hline Tetrix bipunctata (Linnaeus, 1758) & $\mathrm{Pa}$ & $\mathrm{Si}-\mathrm{Pc}$ & $\mathrm{Ch}$ \\
\hline Tetrix subulata (Linnaeus, 1758) & Ho & $\mathrm{Eu}-\mathrm{Pc}$ & $\mathrm{Ch}$ \\
\hline Tetrix tenuicornis (Sahlberg, 1893) & $\mathrm{Pa}$ & $\mathrm{Si}-\mathrm{Pc}$ & $\mathrm{Ch}$ \\
\hline
\end{tabular}

Af African, An Angarian, As Asian, $C$ Central, Ca Caspian, Car Carpathian, Ch Chortobiont, Cos Cosmopolitan, $D a$ Dacian, E East, En Endemic, Eu European, Fi Fissuribiont, G Geobiont, Ho Holarctic, $M a$ Manchurian, Med Mediterranean, $N$ North, $P a$ Palearctic, $P c$ Polycentric, Po Pontic, $S$ South, Si Siberian, Th Thamnobiont, $W$ West

*species found only in the Ukrainian part of the Bereg Plain
We identified three groups of sampling sites based on quantitative multivariate analysis of the Orthoptera assemblages. The 1st PCoA ordination axis represented a gradient from xeric (II: Xeric type) to mesic-humid sites and this separation was independent of land use and disturbance at the sites. The 2nd PCoA axis represented a gradient from humid (Ia) to transitional sites (Ib) (Fig. 2.). The hierarchy of these groups is shown by the cluster analysis (Fig. 3.). Values of the Whittaker's index indicates similar patterns and supported the homogenous character of the humid group and more varied composition of xeric sites (Table 4).

The correspondence between these cluster groups and the a priori categorisation of the sampling sites was highest in case of wetness classes referring to edaphic conditions (Table 3). Only three of the a priori xeric sites was classified as the member of the transitional group and only one a priori mesic site was placed with xeric ones, while the a priori humid sites formed a tight group. The latter humid group contained rather undisturbed abandoned semi-natural sites. Other sites with intensive and extensive land use were split between transitional and xeric groups, while the xeric group contained mainly disturbed and more intensively used land cover types (Table 3).

The humid sites were the most species rich ones and the number of species was also highest in these assemblages. The frequency of thamnobiont species was highest, while the frequency of geobionts was the lowest in these assemblages, reflecting to the dense structure of their habitats. The relatively high frequency of southern faunal elements also illustrated to this character (Table 4). The xeric and mostly disturbed habitats formed the most heterogenous group with high total number of species but the lowest mean species richness. These assemblages were dominated 
Table 3 Correspondence between the cluster groups and a priori categories of studied habitats

\begin{tabular}{llll}
\hline $\begin{array}{l}\text { A priori catego- } \\
\text { ries }\end{array}$ & \multicolumn{2}{c}{ Cluster groups } & $\begin{array}{l}\text { Total } \\
\text { number of } \\
\text { sites }\end{array}$ \\
\cline { 2 - 3 } & Ia: HUMID Ib: TRANS II: XERIC &
\end{tabular}

Land use

\begin{tabular}{|c|c|c|c|c|}
\hline Grazed & & 4 & 4 & 8 \\
\hline Mowed & 1 & 2 & 4 & 7 \\
\hline Abandoned & 3 & & 2 & 5 \\
\hline \multicolumn{5}{|l|}{ Disturbance } \\
\hline High & & 4 & 4 & 8 \\
\hline Medium & 1 & 2 & 3 & 6 \\
\hline Low & 3 & & 3 & 6 \\
\hline \multicolumn{5}{|l|}{ Humidity types } \\
\hline Xeric & & 3 & 9 & 12 \\
\hline Mesic & & 3 & 1 & 4 \\
\hline Humid & 4 & & & 4 \\
\hline $\begin{array}{l}\text { Total number of } \\
\text { sites }\end{array}$ & 4 & 6 & 10 & 20 \\
\hline
\end{tabular}

by chortobiont species mainly belonging to the Angarian faunal type (Table 4).

The grasshopper conservation index (GCI') showed the highest conservation value of Orthoptera assemblages live in wet sites. The values of the two other habitat types were similar and much lower. The mean standardized GCIn' index was 0.56 in both wet and transitional habitats while the lower value of xeric sites also showed the lower conservation value of these sites (Table 4).
According to the results of the IndVal analysis, the most common species of the studied assemblages were Pseudochorthippus parallelus, Conocephalus fuscus, Roeseliana roeselii, Omocstus rufipes and Oecanthus pellucens. The assemblages of xeric sites were characterised by high fidelity and specificity of Stenobothrus crassipes which is the quantitative character species of the xeric group. The transitional habitats had two character species: Chorhippus oschei and Stetophyma grossum. The highest number of character species was assigned to the humid sites where relatively high abundance and co-occurrence of Chorthippus dorsatus, Leptophyes albovittata, Tettigonia viridissima and Ruspolia nitidula were revealed. In the transitional and xeric habitats only one or at least some of them occurred with low abundances (Table 5).

\section{Discussion}

The studied habitats represented the most common secondary grassland types in the study area. Orthoptera assemblages at these sites consisted of more than half ( 28 species) of the Orthopteran species known from the Ukrainian part of the Bereg Plain (52 species, Szanyi et al. 2015a). Beyond the regionally common and abundant species, 13 regionally less common species were also captured, proving the unique character and representativity of the sampling sites. Because of historical causes these locally rare species (e.g. C. dorsalis, B. bicolor, P. fallax, E. brachyptera, C. dispar) were absent in much of their potential habitats, so they could not
Fig. 2 Ordination of Orthoptera samples taken in 2013 in the Ukrainian part of the Bereg Lowland (Euclidean distance, inf. content: 1 st axis $=49 \%, 2$ nd axis $=21.14 \%$ )

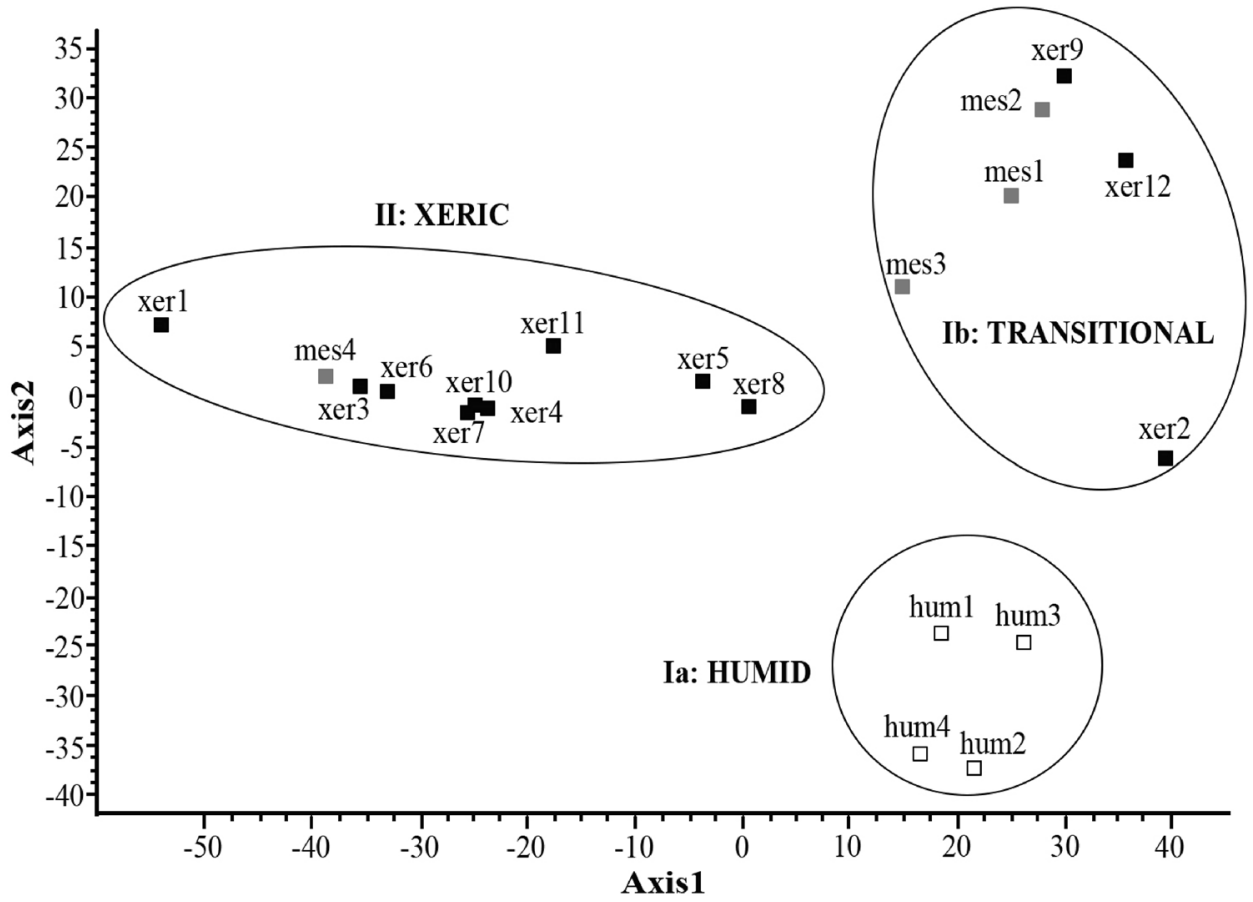


Fig. 3 Cluster analysis of Orthoptera samples taken in 2013 in the Ukrainian part of the Bereg Lowland (Euclidean distance, MISSQ)
Table 4 Main characteristics of assemblage types formed by multivariate analysis

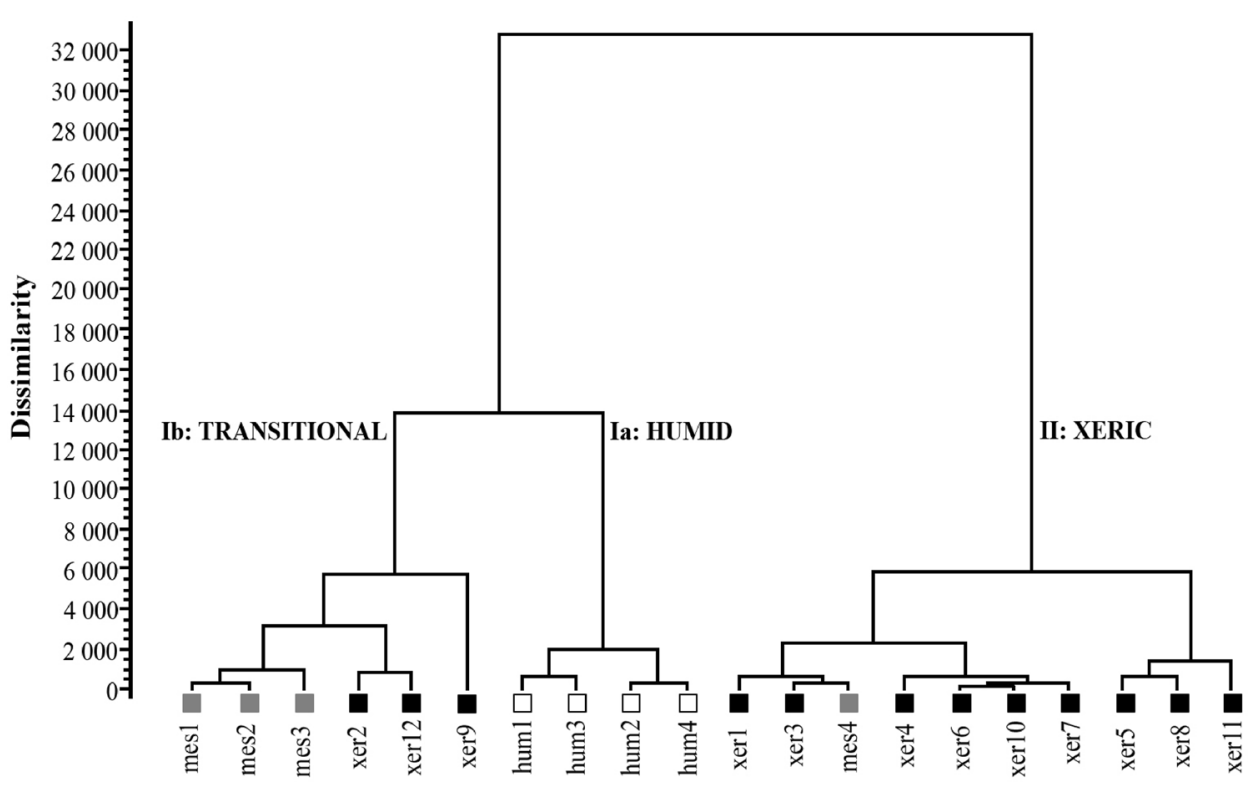

\begin{tabular}{lllll}
\hline & HUMID & TRANS & XERIC & Total \\
\hline Total number of species (S) & 21 & 17 & 20 & 28 \\
Mean number of species $(\alpha \pm \mathrm{SD})$ & $10.00 \pm 1.83$ & $6.83 \pm 2.99$ & $6.50 \pm 1.58$ & $7.30 \pm 2.45$ \\
S/ $\alpha$ (Whittaker) & 2.10 & $2.49 \pm$ & $3.08 \pm$ & $3.84 \pm$ \\
Life forms (mean RF\% \pm SD) & & & & \\
Chortobiont & $65.42 \pm 19.70$ & $79.79 \pm 22.49$ & $84.65 \pm 8.89$ & $79.35 \pm 16.96$ \\
Geo-Chortobiont & $2.19 \pm 4.39$ & $10.28 \pm 22.31$ & $3.74 \pm 8.55$ & $5.39 \pm 13.41$ \\
Thamnobiont & $32.38 \pm 22.06$ & $9.92 \pm 13.03$ & $11.61 \pm 10.12$ & $15.26 \pm 15.74$ \\
Faunal types (mean RF\% SD) & & & & \\
Angarian & $17.95 \pm 6.17$ & $20.23 \pm 6.35$ & $62.12 \pm 13.70$ & $40.72 \pm 24.25$ \\
Siberian-Policentric & $51.98 \pm 8.69$ & $49.70 \pm 14.41$ & $11.83 \pm 6.80$ & $31.22 \pm 22.02$ \\
Mandjurian & $1.49 \pm 1.72$ & $6.73 \pm 8.35$ & $0.37 \pm 1.16$ & $2.50 \pm 5.26$ \\
European-Policentric & $0.00 \pm 0.00$ & $0.57 \pm 0.89$ & $0.00 \pm 0.00$ & $0.17 \pm 0.53$ \\
Ponto-Caspian & $8.55 \pm 3.36$ & $6.69 \pm 9.51$ & $9.34 \pm 6.71$ & $8.39 \pm 6.95$ \\
Ponto-Mediterranean & $10.50 \pm 8.96$ & $5.04 \pm 9.29$ & $10.74 \pm 14.11$ & $8.98 \pm 11.69$ \\
N-Mediterranean-Pc & $2.19 \pm 4.39$ & $0.00 \pm 0.00$ & $1.17 \pm 3.69$ & $1.02 \pm 3.18$ \\
African & $7.33 \pm 9.57$ & $11.05 \pm 22.22$ & $4.45 \pm 8.43$ & $7.01 \pm 13.66$ \\
Siberian (total) & $71.43 \pm 10.70$ & $76.65 \pm 19.06$ & $74.31 \pm 12.74$ & $74.44 \pm 13.93$ \\
South (total) & $28.57 \pm 10.70$ & $23.35 \pm 19.06$ & $25.69 \pm 12.74$ & $25.56 \pm 13.93$ \\
GCI' & $5.65 \pm 1.25$ & $3.86 \pm 1.80$ & $3.39 \pm 0.97$ & $3.98 \pm 1.52$ \\
GCIn' & $0.56 \pm 0.03$ & $0.56 \pm 0.05$ & $0.52 \pm 0.04$ & $0.54 \pm 0.04$ \\
\hline
\end{tabular}

Considering life forms and faunal types Rácz 1998 was followed. Grasshopper conservation indexes (GCI', GCIn') were calculated based on Matenaar et al. (2015) be identified as character species of them. The assemblages were moderately species rich with 7.3 species per site on average.

Two species of community interest according to EU legislation characteristic for wet meadows, I. stysi and $O$. rubripes could not be found in the studied sites. I. stysi is sparsely distributed while $O$. rubripes is widespread in the
Bereg Lowland (Nagy et al. 2015, Szanyi et al. 2015a) but both are absent in many potentially suitable habitats since their special habitat requirements and historic reasons. Although they are especially sensitive for habitat changes, but they are not suitable for indicating naturalness of a wide range of habitats because of their rarity. 
Table 5 Result of IndVal analysis

\begin{tabular}{llllll}
\hline Species & IndVal & & XERIC & TRANS & HUMID \\
\hline Stenobothrus crassipes & 67.50 & $* *$ & $27 / 7$ & $0 / 0$ & $1 / 1$ \\
$\begin{array}{l}\text { Pseudochorthippus paral- } \\
\quad \text { lelus }\end{array}$ & & & & & \\
Conocephalus fuscus & 70.00 & NS & $26 / 7$ & $15 / 3$ & $17 / 4$ \\
Roeseliana roeselii & 60.00 & NS & $34 / 8$ & $23 / 2$ & $9 / 2$ \\
Omocestus rufipes & 55.00 & NS & $23 / 7$ & $5 / 2$ & $4 / 2$ \\
Oecanthus pellucens & 25.00 & NS & $9 / 2$ & $2 / 2$ & $1 / 1$ \\
Chorthippus oschei & 93.34 & $* *$ & $12 / 3$ & $143 / 6$ & $2 / 1$ \\
Stethophyma grossum & 50.00 & $* *$ & $0 / 0$ & $20 / 3$ & $0 / 0$ \\
Tetrix subulata & 33.33 & $?$ & $0 / 0$ & $3 / 2$ & $0 / 0$ \\
Mecostethus parapleurus & 44.23 & $?$ & $3 / 1$ & $21 / 3$ & $2 / 2$ \\
Conocephalus dorsalis & 30.00 & $?$ & $0 / 0$ & $15 / 2$ & $2 / 1$ \\
Chorthippus dorsatus & 80.84 & $* *$ & $14 / 5$ & $14 / 3$ & $63 / 4$ \\
Leptophyes albovittata & 65.74 & $* *$ & $11 / 3$ & $2 / 1$ & $11 / 4$ \\
Tettigonia viridissima & 50.00 & $* *$ & $0 / 0$ & $0 / 0$ & $3 / 2$ \\
Ruspolia nitidula & 49.34 & $* *$ & $8 / 2$ & $3 / 1$ & $10 / 3$ \\
Phaneroptera falcata & 41.21 & NS & $1 / 1$ & $1 / 1$ & $5 / 2$ \\
Stenobothrus lineatus & 39.47 & $?$ & $2 / 1$ & $0 / 0$ & $3 / 2$ \\
Chrysochraon dispar & 25.00 & $?$ & $0 / 0$ & $0 / 0$ & $3 / 1$ \\
Euthistyra brachyptera & 25.00 & $?$ & $0 / 0$ & $0 / 0$ & $1 / 1$ \\
Pholidoptera fallax & 25.00 & $?$ & $0 / 0$ & $0 / 0$ & $3 / 1$ \\
Number of sites (samples) & & & 10 & 6 & 4 \\
\hline
\end{tabular}

Distribution of species with at least 25 IV value amongst cluster groups with highest IV value and number of individuals/occupied sites. For cluster hierarchy see Fig. 2

The dominant species were all chorthobionts and species living in dense or tall grasses (thamno- and chortobionts) reached close to $95 \%$ relative frequencies in the whole sample. High numbers and relative frequencies of Siberian elements reflect the geographic situation and special climatic character of the region, which is the most continental part of the Carpathian Lowland (Zólyomi et al. 1997), and it has been also shown in several other invertebrate taxa (Varga 1992, 1995, 2003; Deli et al. 1995, 1997; Deli and Sümegi 1999; Ködöböcz and Magura 1999; Gálik et al. 2001).

We identified three types of assemblages that were characteristic to different habitat types. These habitat types reflected the a priori climatic (humidity) classification thus the assemblages' composition is mainly driven by climatic factors. Land use and disturbance were only of secondary importance for influencing the composition of these assemblages. In the 19th century, the most extensive European river control project was carried out in the Tisza Valley. The extent of the water related ecosystems was radically decreased by draining the wetlands (Borics et al. 2016). Most of the sites in our study were formed during this period, while climatic effects accentuated these effects.

The presumed original character of the studied grasslands has been preserved by the most species rich and humid habitats contrary to the area loss and isolation. These humid grasslands can be seen as the most valuable habitats based on their GCI' indexes too. Meadows preserved rather hygrophilous Orthoptera assemblages that can be seen as relics of former wildlife. Considering forest patches of the region, same trends were identified both in case of carabid beetles (Ködöböcz and Magura 2005) and Macroheterocera species (Szanyi et al. 2016). The semi-natural meadows were characterised by high numbers of thamnobionts and a relatively balanced ratio of Siberian and Southern faunal elements. The character of the other two remaining types is harder to establish a priori, especially in the case of transitional habitats, because they form less well defined groups. Beyond the quantitative composition, the ratio of life forms and faunal types proved to be also suitable indicators of habitat characteristics. In these mainly xeric, drained grasslands, the ratio of geobionts and the Siberian element were larger than in more humid habitats.

We found C. dorsatus, L. albovitta, T. viridissima and $R$. nitidula to be characteristic of humid habitats. Three of these species were thamnobionts and two of them belonged to the Southern faunal elements. Co-occurrence of these mainly common eurytopic species can help to identify remains of species rich, humid semi-natural grasslands rather than occurrence of rare and endangered species of the region. The transitional type had two character species, C. oschei and $S$. grossum, while for the xeric type only one species was characteristic ( $S$. crassipes). This showed that the assemblages lost most of their species diversity and original character species during drainage of their habitats and later disturbance. Based on intermediate disturbance hypothesis (Wilson 1994; Townsend et al. 1997) transitional habitats can show highest diversity. In our case, lost character species of humid habitats were only partly replaced with other species that were characteristic of xeric habitats, thus the coexistence of hygro- and xerophilous species was not realised and not increase the richness of transitional sites. In this case the disturbances were enough high to decrease the diversity.

Based on Orthoptera assemblages the most important and valuable grassland habitats of the Bereg Region are the remains of humid meadows. These are endangered by two main factors the change of land use (abandonment and intensification) and climatic change. The first can be solved by the legislative protection of the most valuable areas selected based on detailed and actual faunistical and botanical data. The reconsideration of the traditional water management of the region, e.g. water deposition in the channels and former wetlands may slow down the unfavourable processes. The beneficial effect of water replacement and revitalization of wetlands has already been revealed in the Hungarian part of the region (Olajos 2009). The effect of large-scale water deposition in the Vásárhelyi Plan (a national project with large artificial reservoirs along the Tisza River) 
started in 2003, should be monitored in the near future. In the secondary grasslands of the Bereg Lowland and similar grasslands through Europe the occurrence of Orthopteran character species, ratio of life forms and faunal types are suitable indicators of habitat changes especially the changes of habitat structure derived by even anthropogenic or natural causes. Utilizing easy sampling, moderate species numbers and well-known ecology of Orthoptera species distribution, abundance and different indexes e.g. Grasshopper Conservation Index (GCI) are useful tools for evaluation of habitat naturalness and long-term monitoring of grasslands.

Acknowledgements We thank Péter Sólymos for linguistic revision and valuable comments on earlier versions of the manuscript.

Author contributions SS and AN designed the experiment and analysed the data, all authors contributed to writing of the manuscript.

Funding Open access funding provided by University of Debrecen. The study was supported by International Visegrad Fund: Visegrad Scholarship Program (2016) (Serial Number: 51501832).

Code availability During the analysis SynTax 2000, and IndVal 2.0 were used, no computer code was created.

\section{Declarations}

Conflict of interest The authors declare that they have no conflict of interest.

Informed consent Informed consent was obtained from all individual participants included in the study.

Research involving human or animals participants This article does not contain any studies with human participants performed by any of the authors. All applicable international, national, and/or institutional guidelines for the care and use of animals were followed.

Open Access This article is licensed under a Creative Commons Attribution 4.0 International License, which permits use, sharing, adaptation, distribution and reproduction in any medium or format, as long as you give appropriate credit to the original author(s) and the source, provide a link to the Creative Commons licence, and indicate if changes were made. The images or other third party material in this article are included in the article's Creative Commons licence, unless indicated otherwise in a credit line to the material. If material is not included in the article's Creative Commons licence and your intended use is not permitted by statutory regulation or exceeds the permitted use, you will need to obtain permission directly from the copyright holder. To view a copy of this licence, visit http://creativecommons.org/licenses/by/4.0/.

\section{References}

Andersen AN, Ludwig JA, Mowe LM, Rentz DCF (2001) Grasshopper biodiversity and bioindicators in Australian tropical savannas: responses to disturbance in Kakadu National Park. Austral Ecol 26:213-222. https://doi.org/10.1046/j.1442-9993.2001.01106.x
Báldi A, Kisbenedek T (1997) Orthoptera assemblages as indicators of grassland naturalness in Hungary. Agric Ecosyst Environ 66:121129. https://doi.org/10.1016/S0167-8809(97)00068-6

Baur B, Cremene C, Groza G, Rákosy L, Schileyko AA, Baur A, Stoll P, Erhardt A (2006) Effects of abandonment of subalpine hay meadows on plant and invertebrate diversity in Transylvania, Romania. Biol Conserv 132:261-273. https://doi.org/10.1016/j. biocon.2006.04.018

Blois JL, Williams JW, Fitzpatrick MC, Jackson ST, Ferrier S (2013) Space can substitute for time in predicting climate-change effects on biodiversity. PNAS 110(23):9374-9379. https://doi.org/10. 1073/pnas.1220228110

Borics G, Ács É, Boda P, Boros E, Erôs T, Grigorszky I, Kiss KT, Lengyel Sz, Somogyi B, Vörös L (2016) Water bodies in Hungary-an overview of their management and present state. Hidrológiai Közlöny 96(3):57-67

Botlik J (2008) Gát. Száz magyar falu könyvesháza Kht., Budapest

Cigliano MM, Braun H, Eades DC, Otte D (2020) Orthoptera species file. Version 5.0/5.0. <http://Orthoptera.SpeciesFile.org>. Accessed 3 Aug 2020

Cremene C, Groza G, Rákosy L, Schileyko AA, Baur A, Erhardt A, Baur B (2005) Alterations of steppe-like grasslands in Eastern Europe: a threat to regional biodiversity hotspots. Conserv Biol 19:1606-1618. https://doi.org/10.1111/j.1523-1739.2005. 00084.x

Csergő AM, Demeter L, Turkington R (2013) Declining diversity in abandoned grasslands of the Carpathian Mountains: do dominant species matter? PLoS ONE 8:e73533. https://doi.org/10.1371/ journal.pone.0073533

Deli T, Sümegi P (1999) Biogeographical characterisation of SzatmárBereg plain based on the Mollusc fauna. In: Hamar J, SárkányKiss E (eds) The Upper Tisza Valley. Tiscia monograph series, Szeged, pp 471-477

Deli T, Dobó T, Kiss J, Sümegi P (1995) Hinweise über die funktion eines "Grünen Korridors" entlang der Tisza (theiss) aufgrund der Molluskenfauna. Malakológiai Tájékoztató 14:29-32

Deli T, Sümegi P, Kiss J (1997) Biogeographical characterisation of the Mollusc fauna on Szatmár-Bereg Plain. In: Tóth E, Horváth $\mathrm{R}$ (eds) Proceedings of the Research Conservation Management Conference, ANP Füzetek Vol I Aggtelek, Aggtelek, pp 123-129

Dover JW, Spencer S, Collins S, Hadjigeorgiu I, Rescia A (2010) Grassland butterflies and low intensity farming in Europe. J Insect Conserv 15:129-137. https://doi.org/10.1007/s10841-010-9332-0

Dufrêne M, Legendre P (1997) Species assemblages and indicator species: the need for flexible asymmetrical approach. Ecol Monogr 67:345-366. https://doi.org/10.1890/0012-9615(1997)067[0345: SAAIST]2.0.CO;2

Eurostat (2020) Glossary: livestock unit (LSU). https://ec.europa.eu/ eurostat/statistics-explained/index.php/Glossary:Livestock_unit_ (LSU). Accessed 5 Aug 2020

Evans D (2006) The habitats of the European union habitats directive. Biol Environ 106(3):167-173

Fekete G, Varga Z (2006) Magyarország tájainak növényzete és állatvilága. MTA Társadalomkutató Központ, Budapest

Feurdean A, Ruprecht E, Molnár Zs, Hutchinson SM, Hickler Th (2018) Biodiversity-rich European grasslands: ancient, forgotten ecosystems. Biol Conserv 228:224-232. https://doi.org/10.1016/j. biocon.2018.09.022

Gálik K, Deli T, Sólymos P (2001) Comparative malacological investigations on the Kaszonyi Hill (NE Hungary). Malakológiai Tájékoztató 19:81-88

Habel JC, Dengler J, Janišová M, Török P, Wellstein C, Wiezik M (2013) European grassland ecosystems: threatened hotspots of biodiversity. Biodivers Conserv 22:2131-2138. https://doi.org/10. 1007/s10531-013-0537-x 
Habitats Scientific Committee (2013) Interpretation manual of European union habitats. European Commission DG Environment Nature ENV, Brussels, p 144

Harz K (1957) Die Geradflügler Mitteleuropas. VEB Gustav Fischer Verlag, Jena

Harz K (1960) Geradflügler oder Orthopteren (Blattodea, Mantodea, Saltatoria, Dermaptera). In: Dahl F (ed) Die tierwelt Deutschlands und der angrenzenden meeresteile nach ihren merkmalen und nach ihrer lebensweise, vol 46. Gustav Fischer, Teil Jena, p 232

Harz K (1975) Die Orthopteren Europas. Junk Publishers, The Hague

Klijn JA (2004) Driving forces behind landscape transformation in Europe, from a conceptual approach to policy options. In: Jongman R (ed) The new dimensions of the European landscape. Springer, Dordrecht, pp 201-218

Ködöböcz V, Magura T (1999) Biogeographical connections of the carabid fauna (Coleoptera) of the Beregi-síkság to the Carpathians. Folia Ent Hung 60:195-203

Ködöböcz V, Magura T (2005) Forest of the Bereg-Plain as refuges on their carabid fauna (Coleoptera: Carabidae). Acta Phytopath Entom Hung 40:367-382. https://doi.org/10.1556/APhyt.40.2005.3-4.18

Likovitch IM (1957) Nekotorye dannye o faune prjamokrylych (Orthoptera) Zakarpatja. [Some data on Orthoptera fauna of Ukrainian Carpathians]. Doklady i Soobscenia Uzhgorodskogo Universiteta, Seria Biologia 1:61-64

Likovitch IM (1959) K voprosu o vertikalnom raspredelenii prjamokrylych (Orthoptera) v Zakarpate [On vertical distribution of Orthoptera in Ukrainian Carpathians]. Uzhgorodskiy Gosudarstvennyj Universitet Nauchnye Zapisky 40:227-238

Lovassy S (1931) Az Ecsedi-láp és madárvilága fennállása utolsó évtizedeiben. Magyar Tudományos Akadémia, Budapest, p 1931

Matenaar D, Bazelet CS, Hochkirch A (2015) Simple tool for the evaluation of protected areas for the conservation of grasshoppers. Biol Cons 192:192-199. https://doi.org/10.1016/j.biocon.2015.09.023

Meeus JHA, Wijermans MP, Vroom MJ (1990) Agricultural landscapes in Europe and their transformation. Landsc Urban Plan 18:289-352. https://doi.org/10.1016/0169-2046(90)90016-U

Nagy A, Rácz IA (2007) A hazai Orthoptera fauna 10 x 10 km-es UTM alapú adatbázisa. In: Kövics GJ, Dávid I (ed) 12. Tiszántúli Növényvédelmi Fórum: Előadások - Proceedings. Debreceni Egyetem Agrártudományi Centrum, Debrecen pp 198-198

Nagy A, Rácz IA (2014) Magyar tarsza, Stys-tarsza, Erdélyi avarszöcske, Álolaszsáska, Vöröslábú hegyisáska, Eurázsiai rétisáska. In: Haraszthy L (ed) Natura 2000 fajok és élőhelyek Magyarországon. Pro Vértes Természetvédelmi Közalapítvány, Csákvár, pp 190-204

Nagy A, Sólymos P, Rácz IA (2007) A test on the effectiveness and selectivity of three sampling methods frequently used in orthopterological field studies. Entomol Fenn 18:149-159. https://doi.org/10.33338/ ef. 84392

Nagy A, Batiz Z, Szanyi Sz (2015) Orthoptera fauna of the Hungarian part of the Bereg Plain (Northeast Hungary). Bul Inf Soc Lepid Rom 26:64-80

Obenberger J (1926) Rovnokřídlý hmyz (Orthoptera a Dermaptera) Republiky Československé. Fauna et Flora Čechoslovenica I, Praha, p 234

Olajos P (2009) Complex habitat rehabilitation of the Central-Bereg Plain, North-East Hungary. LIFE project- technical final report

Podani J (1997a) Bevezetés a többváltozós biológiai adatfeltárás rejtelmeibe. Scientia, Budapest

Podani J (1997b) SYNTAX 5.1: a new version of PC and Macinthos computers. Coenoses 12:149-152

Poschlod P, Bakker JP, Kahmen S (2005) Changing land use and its impact on biodiversity. Basic Appl Ecol 6:93-98. https://doi.org/10.1016/j. baae.2004.12.001

Poschlod P, Baumann A, Karlík P (2009) Origin and development of grasslands in Central Europe. In: Veen P, Jefferson R, de Smidt J, van der Straaten J (eds) Grasslands in Europe of high nature value. KNNV Publishing, Zeist, pp 15-26
Pungur Gy (1899) Ordo Orthoptera. In: Hungariae FR (ed) Magyar Birodalom Allatvilága. K. M. Természettud. Társ., Budapest, pp 1-16

Rácz I (1998) Biogeographical survey of the orthoptera funa in central part of the Carpathian Basin (Hungary): fauna types and community types. Articulata 13(1):53-69

Schmitt T, Rákosy L (2007) Changes of traditional agrarian landscapes and their conservation implications: a case study of butterflies in Romania. Divers Distrib 13:855-862. https://doi.org/10.1111/j.1472-4642. 2007.00347.x

Simon T (1953) Az Északi-Alföld erdôi. Akadémiai Kiadó, Budapest

Szanyi Sz, Varga Z (2015) Changes in butterfly assemblages of meadows in a Transcarpathian game reserve. Entomol Rom 19:41-50

Szanyi Sz, Katona K, Rácz IA, Varga Z, Nagy A (2015a) Orthoptera fauna of the Ukrainian part of the Bereg Plain (Transcarpathia, Western Ukraine). Articulata 30:91-104

Szanyi Sz, Katona K, Bernát N, Tamási K, Molnár A (2015b) A Nagydobronyi Vadvédelmi rezervátum (Kárpátalja, Nyugat Ukrajna) gyepeinek flórájáról. Tájökológiai Lapok 13(1):1-8

Szanyi Sz, Nagy A, Varga Z (2016) Comparison of Macroheterocera assemblages of four forests in the Bereg Plain (Hungary, Ukraine). Biologia 71(11):1281-1291. https://doi.org/10.1515/ biolog-2016-0154

Szanyi Sz, Nagy A, Varga Z (2018) Diversity and concordance in the composition of butterfly assemblages of the Transcarpathian (Bereg) plain (SW Ukraine). Biologia 73(10):951-964. https://doi.org/10. 2478/s11756-018-0102-x

Townsend CR, Scarsbrook MR, Dolgdec S (1997) The intermediate disturbance hypothesis, refugia, and biodiversity in streams. Limnol Oceanogr 42(5):938-949. https://doi.org/10.4319/lo.1997.42.5.0938

van Zanten BT, Verburg PH, Espinosa M, Gomez-y-Paloma S, Galimberti G, Kantelhardt J, Kapfer M, Lefebvre M, Manrique R, Piorr A, Raggi L, Schaller L, Targetti S, Zasada I, Viaggi D (2014) European agricultural landscapes, common agricultural policy and ecosystem services: a review. Agron Sustain Dev 34(2):309-325. https://doi. org/10.1007/s13593-013-0183-4

Varga Z (1992) Állatföldrajzi szempontból érdekes, védett és veszélyeztetett rovarfajok előfordulása a Beregi-sík szigethegyein. Calandrella 4(1):76-80

Varga Z (1995) Geographical patterns of biological diversity in the Palearctic region and the Carpathian Basin. Acta Zool Acad Sci Hung 41:71-92

Varga Z (2003) A Kárpát-medence állatföldrajza. In: Láng I, Bedő Z, Csete L (eds) Növény állat élőhely. Magyar Tudománytár, Budapest, pp 89-119

Warren MS (1997) Conserving Lepidoptera in a changing environment: a perspective from Western Europe. J Insect Conserv 1:1-4

Wenzel M, Schmitt T, Weitzel M, Seitz A (2006) The severe decline of butterflies on western calcareous grasslands during the last 30 years: a conservation problem. Biol Conserv 28:542-552. https:// doi.org/10.1016/j.biocon.2005.10.022

Whittaker RH (1960) Vegetation of the Siskiyou Mountains, Oregon California. Ecol Monogr 30(3):279-338. https://doi.org/10.2307/ 1943563

Wilson JB (1994) The 'intermediate disturbance hypothesis' of species coexistence is based on patch dynamics. New Zeal J Ecol $18: 176-181$

Zólyomi B, Kéri M, Horváth F (1997) Spatial and temporal changes in the frequency of climatic year types in the Carpathian Basin. Coenoses 12:33-41

Publisher's Note Springer Nature remains neutral with regard to jurisdictional claims in published maps and institutional affiliations. 